\title{
ОСОБЛИВОСТІ СУЧАСНОЇ ГЕНДЕРНОЇ ДИФЕРЕНЦІАЦІї ПАРАНОЇДНОЇ ШИЗОФРЕНІї
}

\author{
๑С. В. Черначук', О. Г. Буздиган ${ }^{2}$, С. І. Шкробот ${ }^{3}$
}

Вінницький національний медичний університет імені М. І. Пирогова ${ }^{1}$

Вінницька обласна психоневрологічна лікарня імені акад. О. І. Ющенка ${ }^{2}$

ДВНз «Тернопільський державний медичний університет імені І. Я. Горбачевського моз україни» ${ }^{3}$

РЕзюМЕ. У статті проаналізовано клініко-анамнестичні та клініко-психопатологічні особливості параноїдної шизофренії з урахуванням гендерного фактора.

Мета - вивчення особливостей сучасної гендерної диференціації клініко-анамнестичних та клініко-психопатологічних особливостей перебігу параноїдної шизофренії.

Матеріал і методи. Проведено клініко-анамнестичне та клініко-психопатологічне обстеження 210 чоловіків та 210 жінок, хворих на параноїдну шизофренію, з використанням шкали PANSS.

Результати. Встановлено, що клінічний патоморфоз депресивних розладів на сучасному етапі характеризується збільшенням поширеності астенічної симптоматики (79,9\% проти 67,4 \%, p<0,01), нездатності концентруватися і приймати рішення (71,4 \% проти 61,0%, p<0,05), тривожної симптоматики (81,0 \% проти 73,7 \%, p<0,05), песимізму $(80,4$ \% проти 79,2 \%, p<0,05), суїцидальних думок $(70,4 \%$ проти 60,2 \%, p<0,05), гастроінтестинальної симптоматики (60,3 \% проти 51,7 \%, p<0,05), інсомнічних проявів $(93,1 \%$ проти $81,8 \%, p<0,01)$, і зменшенням проявів ангедонії $(76,2 \%$ проти 84,3 \%, р<0,05) і заниженої самооцінки $(80,5 \%$ проти 73,0 \%, р<0,05). Виявлено, що інтрасиндромологічна структура депресивних розладів на сучасному етапі характеризується зменшенням поширеності вітальної депресії (з 56,8 \% до 42,9 \%, р<0,05) та анестетичної депресії (з 25,8 \% до 18,0 \%, p<0,05) при збільшенні поширеності апатичних депресій (24,3 \% проти 17,4 \%, р<0,05), наявністю тривожно-фобічних та іпохондричних включень (56,1 \% проти 47,5 \%, р<0,05), інсомнічних порушень у вигляді пресомнічних, інтрасомнічних, постсомнічних проявів з переважанням останніх $(93,1 \%$ проти 81,8 \%, p<0,01), вегето-соматичних розладів та соматизованих проявів у вигляді гетерогенних поліморфних сенестопатій $(77,8 \%$ проти $68,2 \%$, р<0,05), сенестоалгічного синдрому (11,6 \% проти $6,4 \%$, p<0,05), а також астенічної депресії $(79,9 \%$ проти 66,9 \%, p<0,01), ажитованої депресії (38,6 \% проти 30,1%, p<0,05) та депресії зі стрибками ідей $(28,0$ \% проти 20,8 \%, p<0,05).

Висновки. Виявлені закономірності враховані при розробці диференційованих схем лікування параноїдної шизофренії.

КлючОВІ СлОВА: параноїдна шизофренія; гендерна диференціація.

Вступ. Серед факторів, що визначають особливості захворюваності на параноїдну шизофренію (ПШ), одне з провідних місць належить гендерному фактору. Ряд авторів вважають, що посилення впливу гендерного фактора можна розглядати як один із проявів сучасного патоморфозу шизофренії $[1,2]$. Дослідженнями останніх років були виявлені значущі гендерні відмінності у соціально-епідеміологічних характеристиках [3], патогенетичних механізмах і актуальних факторах маніфестації та екзацербації захворювання $[4,5]$, клініко-психопатологічних характеристиках $[6,7]$ та підходах до лікування та реабілітації хворих на параноїдну шизофренію (ПШ) [8]. Водночас, наголошується на винятковій актуальності та важливості вивчення особливостей сучасного патоморфозу ПШ, у т.ч. пов'язаного з впливом гендерного фактора $[9,10]$.

Мета - вивчення особливостей сучасної гендерної диференціації клініко-анамнестичних та клініко-психопатологічних особливостей перебігу ПШ.

Матеріал і методи дослідження. Відповідно до мети роботи з дотриманням принципів біомедичної етики та деонтології було проведено клініко-анамнестичне та клініко-психопатологічне обстеження 420 хворих на ПШ (210 чоловіків та
210 жінок), які перебували на стаціонарному лікуванні у Вінницькій обласній психоневрологічній лікарні імені академіка О. І. Ющенка протягом 2011-2016 років. Критерієм включення пацієнтів в обстеження було встановлення остаточного діагнозу «Параноїдна шизофренія» (F 20.00) відповідно до критеріїв MKX-10. 3 метою стандартизації оцінки клініко-психопатологічної симптоматики була використана психометрична «Кваліфікаційна шкала оцінки вираженості позитивних, негативних і загальних психопатологічних синдромів» PANSS. Відбір хворих для дослідження здійснювали методом сліпої рандомізації. Статистичний аналіз даних проводили з використанням ліцензійного пакета прикладних програм Statistica 6.0 (StatSoft Inc., США). Для оцінки характеру розподілу використано тест Шапіро-Уїлка. Аналіз розбіжностей у кількісних ознаках виконано за допомогою непараметричного тесту Манна-Уїтні, категоріальних ознак-за допомогою точного критерію Фішера у чотирипільних таблицях і критерію $\chi^{2}$ Пірсона у таблицях спряженості. Прийнятним вважали 95,0 \% рівень статистичної значущості розбіжностей $(p<0,05)$.

Результати й обговорення. Середній вік початку захворювання на ПШ у чоловіків виявився 
Огляди літератури, оригінальні дослідження, погляд на проблему, ювілеї

за медіаною на 6,0 років меншим, ніж у жінок (Ме=21,0 років, Q25=18,0 років, Q75=28,0 років у чоловіків проти Ме=27,0 років, Q25=20,0 років, $\mathrm{Q} 75=32,0$ років у жінок, $\mathrm{P}<0,01)$. Водночас, нам не вдалося виявити суттєвих сплесків захворюваності на параноїдну шизофренію у жінок у преклімактеричному та клімактеричному періодах: захворюваність жінок практично повністю повторювала динамікучоловіків, із постійним рівномірним «відставанням» в динаміці на 3-5 років. Динаміка інтенсивно наростала до 30-35 років, з суттєвим зменшенням подальшого темпу зростання, при збереженні відносно плавної кривої динаміки захворюваності; при цьому кумулятивний відсоток захворюваності перетинав 50 \% межу у чоловіків у віці 21 рік, у жінок - у віці 27 років. Такі особливості, на наш погляд, можуть бути зумовлені активним застосуванням у преклімактеричному та клімактеричному віці гормональних препаратів, що може суттєво впливати на ризик виникнення асоційованих з клімаксом захворювань. Середній вік першої госпіталізації з приводу шизофренії у чоловіків був значуще меншим: Ме=23,0 роки, $\mathrm{Q} 25=18,0$ років, Q75=29,0 років проти $\mathrm{Me}=87,0$ років, Q25=21,0 рік, Q75=33,0 роки у жінок, $\mathrm{p}<0,01)$ i склав $24,2 \pm 7,6$ років, у жінок - 27,6 $\pm 8,0$ років ( $<<0,01)$. Середня тривалість захворювання до пер-

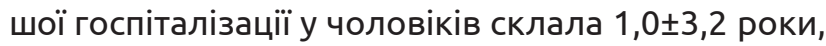
при цьому 82,4 \% хворих госпіталізували у перший рік захворювання, у жінок - відповідно $1,0 \pm 3,0$ роки, $73,3 \%$ ( $>>0,05)$.

у 7,4 \% хворих на ПШ простежувалася обтяжена спадковість на шизофренію за лінією батька (у 9,0 \% чоловіків, у 5,7 \% жінок, р>0,05). Натомість, обтяжена захворюваність за ПШ за лінією матері значуще частіше $(p<0,05)$ виявлялася у жінок: 6,2 \% проти 1,9 \%. В цілому обтяженість на шизофренію за однією лінією виявлена у 21,9 \% жінок та у 15,7 \% чоловіків, за двома лініями - у $2,4 \%$ жінок і у $0,5 \%$ чоловіків $(p<0,05)$.

В цілому обстеженим хворим був притаманний поступовий початок захворювання $(72,1$ \% усіх обстежених), при цьому у чоловіків він зустрічався дещо частіше: 78,1 \% проти 64,3 \% у жінок $(p>0,05)$.

Найбільш поширеними проявами дебюту шизофренії були розлади сну, які виявлені у $91,0$ \% чоловіків та у 91,4 \% жінок ( $>>0,05)$, маячний синдром (по 84,3 \% чоловіків та жінок), та прояви афектів страху і тривоги (76,2 \% чоловіків, 90,0 \% жінок, р<0,01). Серед інших проявів дебюту шизофренії у жінок частіше спостерігалися галюцинації (у 41,4 \% чоловіків та у 53,3 \% жінок, p<0,05), психомоторне збудження (у 55,2 \% чоловіків та у 70,5 \% жінок, р<0,01), напливи думок (у 30,5 \% чоловіків та у 53,8 \% жінок, p<0,01) та голов- ний біль (у 13,3 \% чоловіків та у 31,9 \% жінок, $\mathrm{p}<0,01)$, а у чоловіків - апато-абулічний синдром (у 50,0 \% чоловіків та у 39,0\% жінок, р<0,05). Депресивний синдром та маніакальний стан у чоловіків та жінок траплялися однаково часто (відповідно у 57,1 \% чоловіків та у 57,6 \% жінок; у 8,1 \% чоловіків та у 8,6 \% жінок, р>0,05).

3 основних критеріїв шизофренії у чоловіків значуще частіше виявлялися луна думок, відчуття вкладання або відібрання думок, передача думок на відстань: 17,1 \% проти 11,0 \% у жінок, p<0,05; у жінок - вербальні галюцинації: 54,8 \% проти 39,5 \%, p<0,05. За іншими основними критеріями (маячення оволодіння, впливу, бездіяльності, маячного сприйняття реальності та стійких маячних ідей) значущих розбіжностей між чоловіками і жінками не виявлено.

Загалом у чоловіків виявлено тяжчу шизофренічну симптоматику, ніж у жінок; ця тенденція простежувалась як за інтегральними показниками, так і за окремими симптомами шкали PANSS.

Сумарний бал за шкалою PANSS у чоловіків був значуще більшим, ніж у жінок: $M$ е=108,0 балів, $Q 25=97,0$ балів, Q75=118,0 балів проти $\mathrm{Me}=95,0$ балів, Q25=85,0 балів, Q75=106,0 балів у жінок ( $<0,01)$, як і інтегральний показник тяжкості продуктивної симптоматики: Ме=27,0 бали, $\mathrm{Q} 25=23,0$ бали, Q75=30,0 балів проти $\mathrm{Me}=22,0$ бали, Q25=18,0 балів, Q75=26,0 бали у жінок $(p<0,01)$. У структурі позитивної симптоматики у чоловіків більшими виявилися показники тяжкості маячення: Ме=5,0 балів, Q25=4,0 бали, Q75=6,0 балів проти $\mathrm{Me}=4,0$ бали, Q25=3,0 бали, Q75=5,0 балів у жінок ( $p<0,01)$, розладів мислення: $M e=4,0$ бали, $\mathrm{Q} 25=3,0$ бали, Q75=5,0 балів проти $\mathrm{Me}=3,0$ бали, $\mathrm{Q} 25=3,0$ бали, Q75=4,0 бали у жінок $(p<0,01)$, галюцинацій: Ме=4,0 бали, Q25=2,0 бали, Q75=5,0 балів проти $\mathrm{Me}=4,0$ бали, Q25=2,0 бали, Q75=5,0 балів у жінок $(p<0,01)$, збудження: $M e=4,0$ бали, $\mathrm{Q} 25=3,0$ бали, Q75=5,0 балів проти $\mathrm{Me}=3,0$ бали, $\mathrm{Q} 25=2,0$ бали, Q75=4,0 бали у жінок $(p<0,01)$, ідей величі: $\mathrm{Me}=1,0$ бал, Q25=1,0 бал, Q75=1,0 бал проти $\mathrm{Me}=1,0$ бал, Q25=1,0 бал, Q75=1,0 бал у жінок ( $p<0,05)$, підозріливості та ідей переслідування: $\mathrm{Me}=4,5$ бала, Q25=3,0 бали, Q75=5,0 балів проти $\mathrm{Me}=3,0$ бали, Q25=2,0 бали, Q75=4,0 бали у жінок $(p<0,01)$ та ворожості: $\mathrm{Me}=4,0$ бали, Q25=4,0 бали, $\mathrm{Q} 75=5,0$ бали проти Ме=3,0 бали, Q25=3,0 бали, $\mathrm{Q} 75=4,0$ бали у жінок $(\mathrm{p}<0,01)$.

Чоловікам також була притаманна більша тяжкість негативної симптоматики як інтегрального показника: $M e=28,5$ бала, Q25=22,0 бали, $\mathrm{Q} 75=31,0$ бал проти $\mathrm{Me}=22,0$ балів, Q25=18,0 балів, Q75=27,0 балів у жінок ( $p<0,01)$, так і окремих показників у структурі негативної симптоматики притупленого афекту: Ме=5,0 балів, Q25=4,0 бали, 
Огляди літератури, оригінальні дослідження, погляд на проблему, ювілеї

$\mathrm{Q} 75=5,0$ балів проти $\mathrm{Me}=4,0$ бали, Q25=3,0 бали,

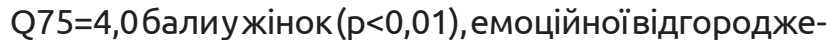
ності: $\mathrm{Me}=5,0$ балів, Q25=4,0 бали, Q75=5,0 бали проти $\mathrm{Me}=3,0$ балів, $\mathrm{Q} 25=3,0$ балів, $\mathrm{Q75}=4,0$ балів у жінок ( $p<0,01)$, труднощів у спілкуванні: $\mathrm{Me}=4,0$ бали, Q25=4,0 бали, Q75=5,0 бали проти $\mathrm{Me}=3,0$ бали, Q25=3,0 бали, Q75=4,0 бали у жінок $(p<0,01)$ та пасивно-апатичної соціальної відгородженості: $\mathrm{Me}=5,0$ балів, Q25=4,0 бали, Q75=5,0 бали проти $\mathrm{Me}=3,0$ бали, Q25=3,0 бали, Q75=5,0 балів у жінок $(p<0,01)$.

Значуще не відрізнялися у чоловіків та жінок показники тяжкості порушень абстрактного мислення: $\mathrm{Me}=3,0$ бали, Q25=3,0 бали, Q75=4,0 бали проти $\mathrm{Me}=3,0$ бали, Q25=2,0 бали, Q75=4,0 бали відповідно, і стереотипного мислення: $\mathrm{Me}=3,0$ бали, Q25=2,0 бали, Q75=4,0 бали проти $\mathrm{Me}=3,0$ бали, Q25=2,0 бали, Q75=4,0 бали відповідно.

У цілому, чоловікам була притаманна більша тяжкість загальної симптоматики шизофренії: $\mathrm{Me}=54,0$ бали, Q25=49,0 балів, Q75=58,0 балів проти $\mathrm{Me}=52,0$ бали, Q25=47,0 балів, Q75=56,0 балів у жінок $(p<0,01)$. У структурі загальної симптоматики шизофренії у чоловіків тяжчими були прояви моторної загальмованості: $\mathrm{Me}=3,0$ бали, $\mathrm{Q} 25=2,0$ бали, $\mathrm{Q75}=4,0$ бали проти $\mathrm{Me}=3,0$ бали, $\mathrm{Q} 25=2,0$ бали, $\mathrm{Q} 75=4,0$ бали у жінок $(\mathrm{p}<0,01)$, малоконтактності: $\mathrm{Me}=4,0$ бали, Q25=3,0 бали, $\mathrm{Q} 75=5,0$ балів проти $\mathrm{Me}=4,0$ бали, $\mathrm{Q} 25=3,0$ бали, $\mathrm{Q} 75=4,0$ бали у жінок $(p<0,01)$, порушень уваги: $\mathrm{Me}=4,0$ бали, Q25=4,0 бали, Q75=5,0 балів проти $\mathrm{Me}=4,0$ бали, Q25=3,0 бали, Q75=4,0 бали у жінок $(p<0,01)$, зниження критичності до свого стану: $\mathrm{Me}=5,0$ балів, Q25=5,0 балів, Q75=6,0 балів проти $\mathrm{Me}=5,0$ балів, $\mathrm{Q} 25=4,0$ бали, $\mathrm{Q75}=6,0$ балів у жінок $(p<0,01)$, порушень волі: Мe=4,0 бали, Q25=4,0 бали, Q75=6,0 балів проти Ме=4,0 бали, Q25=3,0 бали, Q75=5,0 балів у жінок ( $p<0,01)$, послаблення контролю імпульсивності: Ме=3,0 бали, Q25=2,0 бали, Q75=4,0 балипроти Me=3,0 бали, $\mathrm{Q} 25=2,0$ бали, $\mathrm{Q} 75=3,0$ бали у жінок $(p<0,01)$, завантаженості психічними переживаннями: $\mathrm{Me}=5,0$ балів, $\mathrm{Q} 25=4,0$ бали, $\mathrm{Q75}=6,0$ балів проти $\mathrm{Me}=4,0$ бали, $\mathrm{Q} 25=4,0$ бали, Q75=5,0 балів у жінок $(p<0,01)$, та активної соціальної відстороненості: Мe=5,0 балів, Q25=4,0 бали, $\mathrm{Q} 75=5,0$ балів проти $\mathrm{Me}=4,0$ бали, Q25=4,0 бали, $\mathrm{Q} 75=5,0$ балів у жінок $(\mathrm{p}<0,01)$.

Натомість, у жінок тяжчими були прояви афективних порушень: депресії: Мe=4,0 бали, $\mathrm{Q} 25=3,0$ бали, $\mathrm{Q75}=5,0$ балів проти $\mathrm{Me}=4,0$ бали, $\mathrm{Q} 25=3,0$ бали, $\mathrm{Q} 75=5,0$ балів у чоловіків $(\mathrm{p}<0,01)$, почуття провини: $\mathrm{Me}=1,0$ бал, $\mathrm{Q} 25=1,0$ бал, $\mathrm{Q} 75=1,0$ бал проти $\mathrm{Me}=1,0$ бал, Q25=1,0 бал, $\mathrm{Q} 75=1,0$ бал у чоловіків ( $p<0,01)$, тривоги: $\mathrm{Me}=5,0$ балів, $\mathrm{Q} 25=4,0$ бали, $\mathrm{Q75}=5,0$ балів проти $\mathrm{Me}=4,0$ бали, Q25=3,0 бали, Q75=5,0 балів у чоловіків $(p<0,05)$, напруженості: $M e=5,0$ балів, $Q 25=4,0$ бали, $\mathrm{Q} 75=5,0$ балів проти $\mathrm{Me}=4,0$ бали, Q25=4,0 бали, $\mathrm{Q} 75=5,0$ балів у чоловіків $(p<0,05)$, а також манірності і позування: $\mathrm{Me}=1,0$ бал, $Q 25=1,0$ бал, $\mathrm{Q} 75=3,0$ бали проти $\mathrm{Me}=1,0$ бал, Q25=1,0 бал, $\mathrm{Q} 75=2,0$ бали у чоловіків $(p<0,05)$, та соматичного неблагополуччя: $\mathrm{Me}=2,0$ бали, $\mathrm{Q} 25=2,0$ бали, $\mathrm{Q} 75=3,0$ бали проти $\mathrm{Me}=1,5$ бали, Q25=1,0 бал, $\mathrm{Q} 75=2,0$ бали у чоловіків $(p<0,01)$. Не виявлено значущих розбіжностей між чоловіками та жінками за такими симптомами як незвичний зміст думок: $\mathrm{Me}=1,0$ бал, Q25=1,0 бал, Q75=2,0 бали проти $\mathrm{Me}=1,0$ бал, Q25=1,0 бал, Q75=2,0 бали відповідно, та дезорієнтованість: $\mathrm{Me}=1,0$ бал, Q25=1,0 бал, $\mathrm{Q} 75=1,0$ балв проти $\mathrm{Me}=1,0$ бал, Q25=1,0 бал, Q75=1,0 бал відповідно.

У чоловіків більшою була виразність анергії: $\mathrm{Me}=14,0$ балів, Q25=12,0 балів, Q75=15,0 балів проти Me=11,0 балів, Q25=9,0 балів, Q75=13,0 балів у жінок $(p<0,01)$, порушень мислення: $\mathrm{Me}=$ 11,0 балів, Q25=9,0 балів, Q75=13,0 балів проти $\mathrm{Me}=10,0$ балів, Q25=7,0 балів, Q75=11,0 балів у жінок ( $p<0,01)$, збудження: Мe=10,0 балів, Q25=9, 0 балів, $Q 75=11,0$ балів проти Me=9, 0 балів, Q25=8,0 балів, Q75=11,0 балів у жінок ( $p<0,01)$, та параноїдної поведінки: Ме=12,0 балів, Q25=10,0 балів, $\mathrm{Q} 75=14,0$ балів проти Ме=10,0 балів, Q25=8,0 балів, Q75=12,0 балів у жінок $(p<0,01)$.

Отримані нами результати свідчать про наявність клініко-функціональних розбіжностей у розвитку і перебігу ПШ у жінок і чоловіків, асоційованих з гендерним фактором.

Висновки. 1.Клініко-анамнестичнедослідження особливостей перебігу параноїдної шизофренії у чоловіків та жінок виявило істотні відмінності, асоційовані з гендерним фактором. У жінок це більша спадкова обтяженість як за однією, так і за двома сімейними лініями, більш пізній та поступовий дебют захворювання з більш вираженими афектами страху і тривоги та різноманітністю клінічних проявів, а у чоловіків - більш гострий початок захворювання з психомоторним збудженням або апато-дистимічними проявами.

2. За результатами клініко-психопатологічного дослідження виявлено значущі розбіжності у проявах клінічної симптоматики параноїдної шизофренії у чоловіків та жінок. Встановлено, що у чоловіків значуще частіше виявлялася деперсоналізаційна симптоматика, а у жінок - галюцинаторна. Виявлено, що у структурі продуктивної симптоматики чоловікам притаманні більш важкі прояви маячення, розладів мислення, галюцинацій, збудження та ворожості; в структурі негативної симптоматики - притуплення афекту, емоційної відгородженості, труднощів у спілкуванні та пасивно-апатичної соціальної відгородженості; а 
Огляди літератури, оригінальні дослідження, погляд на в структурі загальної симптоматики - моторної загальмованості, малоконтактності, порушень уваги, зниження критичності до свого стану, порушень волі, послаблення контролю імпульсивності, завантаженості психічними переживаннями та активної соціальної відстороненості. У жінок більш тяжкими є прояви афективних порушень: депре-

\section{ЛІТЕРАТУРА}

1. Юрьева Л. Н. Шизофрения : клиническое руководство для врачей / Л. Н. Юрьева. - К. : Сфера, 2010. С. 24.

2. Гнатишин М. С. Шизофренія : сучасний погляд / М. С. Гнатишин, О. О. Белов. - Вінниця: Консоль, 2012. 205 c.

3. Дзеружинская Н. А. Гендерные различия показателей социальных потерь у больных параноидной шизофренией / Н. А. Дзеружинская, В. А. Ломтева // Архів психіатрії. - 2016. - Т. 22, № 1 (84). - С. 47-52.

4. Ханько А. В. Гендерные особенности адаптации к болезни у пациентов с первыми приступами параноидной шизофрении / А. В. Ханько // Вестник ЮжноУральского государственного университета. - 2014. Вып. № 1, Т. 7. - С. 44-49.

5. Eaton K. A Sex-specified effect of obstetrical complications in symptoms of schizophrenia / Kristen E. Eaton, Bernard J. Gallagher, Brian J. Jones, // Clinical Schizophrenia \& Related Psychoses. - 2014. - No. 3. - P. 143-149.

6. Female Specific Association between NNMT Gene and Schizophrenia in a Han Chinese population / Guo-xia

\section{REFERENCES}

1. Yuryeva, L.N. (2010). Shizofreniya: klinicheskoe rukovodstvo dlya vrachey [Schizophrenia: Clinical guide for physicians]. Kyiv: Sfera [in Russian].

2. Hnatyshyn, M.S., \& Belov, O.O. (2012). Shyzofreniia: suchasnyi pohliad [Schizophrenia: a modern look]. Vinnytsia: Konsol [in Ukrainian].

3. Dzeruzhinskaya, N.A., \& Lomteva, V.A. (2016). Gendernye razlichiya pokazateley sotsialnykh poter u bolnykh paranoidnoy shizofreniey [Gender differences in social indicators of loss in patients with paranoid schizophrenia]. Arkhiv Psykhiatrii - Archives of Psychiatry, 1 (84), 47-52 [in Ukrainian].

4. Hanko, A.V. (2014). Gendernye osobennosti adaptatsii k bolezni u patsientov s pervymi pristupami paranoidnoy shizofrenii [Gender features of adaptation to the disease in patients with first-episode paranoid schizophrenia]. Vestnik Yuzhno-Uralskogo Gos. Univer-ta - Bulletin of South Ural State University, 1 (7), 44-49 [in Russian].

5. Eaton, K.E., Gallagher, J.B., \& Jones, B.J. (2014). Sex-specified effect of obstetrical complications in symptoms of schizophrenia. Clinical Schizophrenia \& Related Psychoses, 3, 143-149. сії, почуття провини, тривоги, напруженості, а також манірності і позування.

Перспективи подальших наукових досліджень зосереджені насамперед у сфері розробки адресних комплексних лікувально-реабілітаційних та профілактичних заходів щодо параноїдної шизофренії з урахуваннями виявлених гендерних особливостей.

Wang, Yong Zhang, Zhuang-wei Le [et al.] // International Journal of Medical Scientific. - 2014. - Vol. 11 (12). P. 1234-1239.

7.БобровниковаА.С.Гендерныеразличия развития шизофрении/А.С. Бобровникова, С. Ю. Тарасова //Вестник новых медицинских технологий. - 2015. - № 9 (4). C. 2-5.

8. Ceskova E. Importance of gender in the treatment of schizophrenia / E. Ceskova, P. Prikryl // Primary Care Companion for CNS Disorders. - 2012. - Vol. 14 (6). P. 140-147.

9. Морванюк Г.В.Гендерний підхід в діагностиці та лікуванні параноїдної шизофренії: автореф. дис. на здобуття наукового ступеня канд. мед. наук: 14.01.16 / Морванюк Ганна Володимирівна; ДУ «нститут неврології, психіатрії та наркології НАМН України. - Харків, 2016. - 24 c.

10. Малеваная О. В. Реабилитация и социальное функционирование больных параноидной шизофренией / О. В. Малеваная, Н. Н. Петрова // Тюменский медицинский журнал. - 2012. - № 3. - С. 10-11.
6. Guo-Xia Wang, Yong Zhang, Zhuang-Wei Le, Mao Sun, Dan Wu, Xin-Yu Chen, \& Yuan-Ming Wu (2014). Female Specific Association between NNMT Gene and Schizophrenia in a Han Chinese population. International Journal of Medical Scientific, 11 (12), 1234-1239.

7. Bobrovnikova, A.S., \& Tarasova, S.Yu. (2015). Gendernye razlichiya razvitiya shizofrenii [Gender differences in schizophrenia]. Vestnik novykh med. tekhnologiy - Bulletin of New Medical Technologies, 9 (4), 2-5 [in Russian].

8. Ceskova, E., \& Prikryl, R. (2012). Znachenie pola v lechenii shizofrenii [Importance of gender in the treatment of schizophrenia]. Primary Care Companion for CNS Disorders, 14 (6), 140-147.

9. Morvaniuk, H.V. (2016). Hendernyi pidkhid $v$ diahnostytsi ta likuvanni paranoidnoi shyzofrenii [The gender approach in the diagnosis and treatment of paranoid schizophrenia]. Kharkiv: State Establishment "Institute of Neurology, Psychiatry and Narcology AMS of Ukraine" [in Ukrainian].

10. Malevanaya, O.V., \& Petrova, N.N. (2012). Reabilitatsiya i sotsialnoye funktsionirovaniye bolnykh paranoidnoy shizofreniey [Rehabilitation and social functioning of patients with paranoid schizophrenia]. Tyumenskiy med. zhurn. - Tyumen Medical Journal, 3, 10-11 [in Russian]. 


\title{
Огляди літератури, оригінальні дослідження, погляд на проблему, ювілеї ОСОБЕННОСТИ СОВРЕМЕННОЙ ГЕНДЕРНОЙ ДИФФЕРЕНЦИАЦИИ ПАРАНОИДНОЙ ШИЗОФРЕНИИ
}

\author{
๑С. В. Черначук ${ }^{1}$, Е. Г. Буздыган ${ }^{2}$, С. И. Шкробот ${ }^{3}$
}

Винницкий национальный медицинский университет имени Н. И. Пирогова ${ }^{1}$

Винницкая областная психоневрологическая больница имени А. И. Ющенко ${ }^{2}$

ДВНЗ «Тернопольский государственный медицинский университет имени И. Я. Горбачевского МОЗ Украины» ${ }^{3}$

РЕзЮМЕ. В статье проанализированы клинико-анамнестические и клинико-психопатологические особенности параноидной шизофрении с учетом гендерного фактора.

Цель - изучение особенностей современной гендерной дифференциации клинико-анамнестических и клинико-психопатологических особенностей течения параноидной шизофрении.

Материал и методы. Проведено клинико-анамнестическое и клинико-психопатологическое обследование 210 мужчин и 210 женщин, больных параноидной шизофренией, с использованием шкалы PANSS.

Результаты. Установлено, что клинический патоморфоз депрессивных расстройств на современном этапе характеризуется увеличением распространенности астенической симптоматики $(79,9$ \% против 67,4 \%, p<0,01), неспособности сконцентрироваться и принимать решения $(71,4 \%$ против $61,0 \%$, р<0,05), тревожной симптоматики (81,0 \% против 73,7\%, р<0,05), пессимизма (80,4 \% против 79,2\%, р<0,05), суицидальных мыслей (70,4 \% против $60,2 \%, p<0,05)$, гастроинтестинальной симптоматики (60,3 \% против 51,7\%, p<0,05), инсомнических проявлений (93,1\% против 81,8 \%, p<0,01), и уменьшением проявлений ангедонии $(76,2 \%$ против 84,3\%, р<0,05) и заниженной самооценки $(80,5$ \% против $73,0 \%$, р $<0,05)$. Выявлено, что интрасиндромологическая структура депрессивных расстройств на современном этапе характеризуется уменьшением распространенности витальной депрессии (с 56,8 \% до $42,9 \%$, p<0,05) и анестетической депрессии (с 25,8 \% до 18,0\%, p<0,05) при увеличении распространенности апатичных депрессий (24,3\% против 17,4 \%, р<0,05), наличием тревожно-фобических и ипохондрических включений $(56,1 \%$ против 47,5 \%, р<0,05), инсомнических нарушений в виде пресомнических, интрасомнических, постсомнических проявлений с преобладанием последних $(93,1 \%$ против $81,8 \%, \mathrm{p}<0,01)$, вегето-соматических расстройств и соматизированных проявлений в виде гетерогенных полиморфных сенестопатий $(77,8$ \% против 68,2 \%, р<0,05), сенесто-алгического синдрома $(11,6 \%$ против $6,4 \%, p<0,05)$, а также астенической депрессии $(79,9 \%$ против 66,9\%, p<0,01), ажитированной депрессии (38,6 \% против 30,1\%, p<0,05) и депрессии с прыжками идей $(28,0 \%$ против 20,8 \%, p<0,05).

Выводы. Выявленные закономерности учтены при разработке дифференцированных схем лечения параноидной шизофрении.

КЛЮЧЕВЫЕ СЛОВА: параноидная шизофрения; гендерная дифференциация.

\section{FEATURES OF MODERN GENDER DIFFERENTIATION OF PARANOID SCHIZOPHRENIA}

\section{OS. V. Chernachuk', O. H. Buzdyhan², S. I. Shkrobot ${ }^{3}$}

M. Pyrohov Vinnytsia National Medical University ${ }^{1}$

O. Yushchenko Vinnytsia Regional Psychoneurological Hospital ${ }^{2}$

I. Horbachevsky Ternopil State Medical University ${ }^{3}$

SUMMARY. This article analyzes the clinical and medical history, clinical and psychopathological features of paranoid schizophrenia, taking into account the gender factor.

The aim of the study - to learn the characteristics of modern gender differentiation of clinical and anamnestic, clinical and psychopathological features of the paranoid schizophrenia.

Material and Methods. A clinical anamnesis, clinical and psychopathological observation of 210 men and 210 women with paranoid schizophrenia using a rating PANSS scale was conducted.

Results and Discussion. It was established that the clinical pathomorphosis of depressive diseases on an important stage was characterized by a degree of asthenic symptomatology $(79.9 \%$ against $67.4 \%, p<0.01)$, lack of concentration, and decision solving (71.4 \% against $61.0 \%$, p<0.05) фтчшщгы symptomatology $(81.0 \%$ against $73.7 \%, p<0.05)$, pessimism ( $80.4 \%$ against $79.2 \%, p<0.05)$, suicidal thoughts $(70.4 \%$ against $60.2 \%, p<0.05)$, gastrointestinal symptoms (60.3\% against $51.7 \%, p<0.05)$, negative symptoms and symptoms (93.1\% against $81.8 \%, p<0.01)$, and decrease of manifestations in anhedonia $(76.2 \%$ against $84.3 \%, p<0.05)$ and underestimated self-interest $(80.5 \%$ against $73.0 \%$, $\mathrm{p}<0.05)$. It was found that the intra-syndromological structure of depressive disorders at the present stage is characterized by a decrease in the prevalence of vital depression (from $56.8 \%$ to $42.9 \%$, p<0.05) and anesthetic depression (from $25.8 \%$ to $18.0 \%, \mathrm{p}<0.05)$ with an increase in the prevalence of apathy depression ( $24.3 \%$ vs. $17.4 \%$, $p<0.05)$, anxietyphobic and hypochondria inclusions ( $56.1 \%$ vs. $47.5 \%, \mathrm{p}<0.05)$ ), insomnitic disturbances in the form of presmonic, intrasomnitic, post-semantic manifestations with the prevalence of the latter $(93.1 \%$ vs. $81.8 \%$, p<0.01), vegetativesomatic disorders and somatized manifestations in the form of heterogeneous polymorphic senestopathy $(77.8 \%$ versus $68.2 \%, p<0.05)$, senesto-Alzheimer's syndrome (11.6 \% vs. $6.4 \%, p<0.05)$ and asthenic depression $(79.9 \%$ vs. $66.9 \%$, $\mathrm{p}<0.01)$, aged depression ( $38.6 \%$ vs. $30.1 \%, p<0.05)$ and depression with jumping ideas $(28.0 \%$ vs. $20.8 \%, p<0.05)$.

Conclusions. Identified patterns are taken into account in the development of differentiated treatment regimens of paranoid schizophrenia.

KEY WORDS: paranoid schizophrenia; gender differentiation. 